https://doi.org/10.19195/0137-1150.173.30

Data przesłania artykułu: 29.09.2019

Data akceptacji artykułu: 2.01.2020

\author{
MIROSLAV KOTÁSEK
}

Uniwersytet Masaryka, Brno, Czechy

\title{
Terre I. Bl.: Ivan Blatný a (re)konstrukce jeho místa v české kultuře
}

Poté, co se Ivan Blatný nevrátil v březnu roku 1948 z cesty do Velké Británie, téměř okamžitě následovaly veřejné odsudky, a to $\mathrm{v}$ rozmanitých podobách (připomínám třeba báseň Josefa Kainara, která vyšla ve Svobodných novinách již 3. dubna). V dřívějším prohlášení výboru Klubu mladých spisovatelů ze 30. března 1948, podepsaném mimo jiné Egonem Hostovským, Kamilem Bednářem, Jiřinou Haukovou a Josefem Hiršalem, se dočteme následující:

Čin Ivana Blatného, konfrontován s požadavky všech řečníků na dobřǐšské konferenci a osvětlen jejím ovzduším, jeví se jako nízkost lidská, básnická i politická, jako vědomá lež, žádající bezodkladně spropitné, a jako dok on alá sebevražda někoho, komu jsme donedávna ř́kali český básník. Ivan Blatný od svého vstupu na cizí půdu navždy zemřel pro českou literaturu [zvýraznil M. K.] ${ }^{1}$.

Důvod, proč vybírám právě tento citát, je nabízející se možnost doslovného čtení: kultura a její zástupci zde vyslovují trest smrti in absentia (byt' maskovaný „sebevraždou“); kultura tu prostřednictvím svých „reprezentantü“ vylučuje, vypuzuje za své hranice Ivana Blatného, a tím tyto hranice samožrejmě zároveň definuje, delimituje. A tak (opět doslovně) vlastně Blatný umírá několikrát nebo naopak žije životů několik, přičemž ten ,exilový“ je z pohledu české kultury a prizmatem zmíněného rozsudku ,životem po životě“.

Odolat pokušení operovat ve spojitosti s Ivanem Blatným „smrtí“ se jeví jako velmi obtížné, ne-li nemožné: např́íklad vzpomínkový pořad věnovaný dílu a životu Ivana Blatného byl v roce 1992 uváděn v pražské Viole pod názvem „Básník zaživa pohřbený“". U Jiř́ho Trávníčka se pak dočteme (téměř padesát let po výše citovaném odsudku):

1 I. Blatný, Texty a dokumenty 1930-1948, ed. J. Trávníček, Brno 1999, s. 345. 
Rokem 1979, kdy vyšla sbírka Stará bydliště, se v české literatuře zrodil nanovo básník, o němž se už - mimo kruhy lidí mu nejbližších — ani věrohodně nevědělo, zda vůbec žije [...] andělem Blatného básnické spásy je Frances Meachamová“ [zvýraznil M. K.] ${ }^{2}$.

Literární vědec tu poučen historí české literatury po roce 1945 se znalostí životopisu onoho „druhého“ Blatného života vlastně konstatuje, že onen výše zmíněný rozsudek byl úspěšně vykonán, Blatný vymazán z české kultury. Zároveň však posouvá celý život Blatného po jeho emigraci do polohy kvazi-mýtického př́běhu o zmrtvýchvstání, v němž dokonce nechybí ani „andělé“. To, že se toto zmrtvýchvstání děje prostřednictvím knihy, by nás překvapit nemělo, nebot' na provázanost literatury a života $u$ Blatného ještě narazíme, byt' $v$ tomto př́padě je toto propojení jiného druhu, než mě bude zajímat později. Literárněvědná homiletika. Literatura, kniha dává život — život po smrti.

Onu jinou podobu vpravdě „fatálního“, osudového propojení života a literatury nabízí např́klad Martin Pluháček v doslovu k vydání Starých bydlišt’ z roku 1992:

posledních dvanáct let svého života denně usedal s cigaretou a šálkem čaje ke školnímu sešitu, aby neustálým psaním propletl svůj život s poezií natolik, že nebylo více možno oddělit jedno od druhého. To už byl Ivan Blatný básníkem skutečně totálním, mužem, pohybujícím se v jakémsi prazvláštním čtvrtém rozměru, kde jest ho uviděti, avšak nemožno s ním komunikovati ${ }^{3}$.

Jistě lze tento „výklad“ číst jako laciný, romantizující, patetický popis, nebo jako diskurz stejně mytizující, jako je ten Trávníčkův. Odhlédnu-li však od rétoriky, říká Pluháčkův citát cosi, co mě zajímá a pojmenovává důvod, jenž mě nutí se $\mathrm{v}$ konfrontaci s Blatného exilovým psaním ptát novým způsobem po tom, co je to autobiografie. Hlavní otázka je, jak přistupovat k Blatného psaní, nechci-li (domnívám-li se, že nemohu nebo nejsem schopen) oddělovat jednotlivé básně od způsobu jejich vzniku, od zdravotní, životní situace Blatného, od jeho života a smrti (,skutečné“ i té „symbolické“, vykonané diskurzivně), od jeho místa uvnitřr/vně české kultury. Předesílám, že neexistuje žádná jediná metodologie, která by cosi podobného umožnila. Avšak jedním z mnoha možných vodítek může být Jacques Derrida, jenž ve své Otobiografii věnované „,autobiografii“ Friedricha Nietzsche konstatuje: „A discourse on life/death must occupy a certain space between logos and gramme [...]. And since life is on the line, the trait that relates the logical to the graphical must also be working between the biological and biographical, the thanatological and thanatographical“"4. Považuji tento citát za inspirativní přesto, že Blatný nepromlouvá „o“ životu a smrti, ale spíše přináší promluvu života a smrti, a také promluvu života po životě či života po smrti. Nejen z těchto důvodů není Blatný autobiografickým autorem v běžném smyslu toho slova: není tím, kdo podává (historický, narativní, kauzální) popis a výklad svého dosavadního života, a nevyužívá svou pamět', aby takový soudržný po-

2 J. Trávníček, Pod sankci paměti, [in:] idem, Poezie posledni možnosti, Praha 1996, s. 166.

3 M. Pluháček, Ivan Blatný, [in:] idem, Stará bydliště, Brno 1992, s. 108.

4 J. Derrida, The Ear of the Other, přel. P. Kamuf, New York 1985, s. 4-5. 
pis legitimizoval či dokladoval. Je však ,autobiografickým“ ve smyslu hlubším a významnějším. Tento hlubší význam nám poodkrývá do důsledků domýšlená etymologie slova „auto-bio-grafie“, která už nemá nic společného s reprezentací toho, co bylo, představuje život a smrt jako to, co se píše, jako to, v co jsem vpisován, co si předepisuji: „I am a stranger in this country / I don’t know what fish I fish / all what I want is to stay alive / there is no time to stop" ${ }^{\prime 5}$.

Jedněmi z nejčastějších slov, která Blatný ve svých básních použivá, jsou „hřbitov“ (spolu s významově př́íbuznými „hrob“, „mrtvý“, „smrt“) „,nemocnice“ a „surrealismus“. Nemocnice v několika podobách — jako označení nejčastějších míst jeho pobytu v Británii (to jsou ony různé mental hospitals, jimiž prošel), jako vzpomínka na porodnici, která se v Brně nacházela hned naproti jeho domu, na druhé straně Obilního trhu, stejně jako vzpomínky na brněnskou Nemocnici u Sv. Anny; hřbitov jako místo „melancholických procházek“, ale (ted’ už mimo významové pole Blatného básní, nikoli však mimo významové pole auto-bio-grafie) také jako Centrální hřbitov v Brně, kam si česká kultura/česká společnost/ Československý stát popel ted' už skutečně mrtvého básníka převezl/umístil a tím jej repatrioval, přenesl jej po jeho skutečné smrti zase „domư“. U Blatného jsou tak život a smrt spojovány především $\mathrm{s}$ institucemi, které se o ně profesionálně „staraji““, zabývají se jejich udržováním a „správným“ zakončením, v př́padě „hřbitova“" pak navíc usilují udržovat vzpomínku na „básníka“ (v podobě náhrobku, pamětní desky).

Narození, život, zdraví, nemoc, smrt. Život ve stínu a v područí diagnóz, odsudků, rozsudků, vyhoštění, pietních aktů. Život a smrt připisované, vpisované do těla člověka (diagnóza jakožto diskurz, jenž rozhoduje o tom, kde a jakým způsobem, $v$ jakém režimu je možno člověku žít — at' už to onomu konkrétnímu jedinci jakkoli vyhovuje nebo je s takovým režimem smířen třeba $v$ důsledku uvědomované neschopnosti sám se o sebe postarat). Smrt symbolická, smrt skutečná. Zmínil jsem, že Blatný není „životopiscem“ narativním. Tím, co mu umožňuje jednotlivé významy spojovat neorganizovaně, nekauzálně, nehistoricky, je zmiňovaný „surrealismus“ (ale samozřejmě i „poezie“ jako taková). Surrealismus tak není jen ozvěnou Blatného fascinace avantgardním směrem, Nezvalem, meziválečnou avantgardou obecně, ale stává se $\mathrm{v}$ mnoha jeho exilových básních principem, který umožňuje spojovat i zmíněné antropologické konstanty a jejich konstitutivní prvky mimoběžně, souběžně, nesoudržně, asociativně, v podobě koláže, fragmentu.

Pozoruhodné je, že i když literární věda rozpoznává tento základní pohyb v Blatného poezii a mluví třeba o ,asociačním proudu neseném rytmem psaní“6, vzápětí většinou podléhá hermeneutickému pokušení a extaticky se pokouší vyčerpávajícím způsobem doložit, odkud jednotlivé asociace přicházejí a proč je nakonec výstavba Blatného básní vlastně navýsost logická a vystačí si s úrovní významu — významových, akustických, vizuálních a psychologických spojů, kte-

5 I. Blatný, Pomocná škola Bixley, ed. A. Petruželka, Praha 2011, s. 122.

6 J. Trávníček, Pod sankcí paméti..., s. 167. 
ré je ovšem možné vystopovat ke konečnému, úspěšnému výkladu jednotlivých básní. „Náhoda“, o níž Trávníček ve spojitosti s Blatného poezií také mluví, se tak samotným pokusem o interpretaci stává „nutnostíc, přičemž především z výkladů básní z Pomocné školy Bixley vyplývá, že „cílem“ čtení Blatného je sledování a rekonstrukce Blatného asociací. Nejen cílem čtení, ale i cílem psaní. Jako by Blatný skládal intelektuální, hermeneutické hlavolamy. Při takovém př́stupu ovšem zůstává ukryt hlavní hybný moment Blatného poezie, poezie spjaté s pamětí: její tělesnost, psaní jako činnost, byt' reflektovaná; literatura jako spojování nespojitelného, nelogického: skrze zvuk, falešnou etymologii, chybný pravopis. Zavedením logiky do nelogického, nutného do náhodného, realistického do surrealistického tak nečteme poezii jako poezii, ale stává se z ní logická hádanka, při jejímž řešení je nutné si vypomoci mimo jiné i Blatného biografí, a to jako něčím, co je těmto textům vnější. Hermeneutika tak v konečném důsledku redukuje počet významových spojení, zatímco Blatného poezie dokladuje naopak literaturu jako prostor či spíše činnost, která vytváŕí spojení stále nová, rozšiřuje významové pole, napojuje jeden význam na myriádu významů dalších, třeba prostřednictvím slov zkomolených, chybně pochopených, chybně zapamatovaných, chybně zapsaných, chybně etymologizovaných. „,[M]oje dílo se nedá nijak vysvětlit“"7. Psaní je bezedné, snad coby poukaz na chaotičnost, fragmentárnost paměti či života, ovšem nikoli bezedné po způsobu kombinatorickém, jak jej nacházíme v některých podobách experimentální poezie šedesátých let, spíše jako hledání nových spojení (prostřednictvím zvuku, grafické podoby, chyby) kudy utéci z oblasti klasicky (logicky, kauzálně chápaného) smyslu. Jak zapsat život? Surrealisticky.

Ale také ,„poeticky“, prostřednictvím básně. Narativní podoba paměti kontroluje mnohost a náhodnost prostřednictvím nejsilnějšího reduktivního faktoru, totiž ve jménu narativní, temporální kauzality či chronologie, zatímco poezie se tomuto redukcionismu podvolovat nemusí. Ostatně se stačí podívat, jak nakládá Blatný s časem v jediné básni: čas historický, mytický, čas osobní a veřejný, to vše se zde prolíná, prostupuje:

Capri where Gracie Fields died / in the age of 82 years / Aquillo / Leo Aquilla vstoupil na římský trůn 825 před Kristem / topilo se jenom dřívím nebyl uhlobaron / nebyli stachanovci plán a protiplán / co víme o dějinách země / odtrhla se od slunce když letěla kolem jiná planeta / začala kroužit kolem matky slunce / za tři sta milionů let vznikla protoplasma v moři / moře ustoupilo a ryby zůstaly na suchu / naučily se dýchat / z žáber byly plíce / nejroztodivnější živočichové létali nad ní už v prvohorách / člověk vynalezl stůl / zde sedím a jinak nemohu / odmítám depresi / chci se učit o prvohorách druhohorách / třetihorách a čtvrtohorách / dinosaurus pochází z druhohor / pterodaktylus z třetích / závidím bohům jejich vševědoucnost ${ }^{8}$.

Často také u Blatného narážíme na to, že tam, kde jedna báseň skončila, druhá začíná: třeba citací posledního verše, opakováním slov, nebo „antiiluzivním““ poukazem na to, že o tom či onom psal Blatný včera, minule a podobně. Tato po-

\footnotetext{
${ }^{7}$ I. Blatný, Pomocná škola Bixley..., s. 109.

8 Ibidem, s. 64.
} 
tenciální neukončenost básně upozorňuje, že „báseň“ je možné jako klasifikační pojem u Blatného využívat jen provizorně, nebot' zde na sebe upozorňuje psaní coby na kontinuální „tvorbu“ — pro čtenáře je toto kontinuum deformované tím, že má $\mathrm{k}$ dispozici jen výbor z texti̊. Zároveň tímto způsobem Blatný v mnohém ilustruje princip fungování paměti, jak jí rozumím: tedy nikoli pamět' coby archív vědomostí, jak naznačuje Trávníček, ale soubor nestabilních významů, které lze provazovat a reorganizovat novými způsoby. Vzpomínky nejsou pevné body, které je možné kontrolovaným způsobem propojovat; vzpomínky se mění, transformují a spoluvytvářejí tím, že je zapíšu. A s proměnou vzpomínek se měním i já. Proto také čistě hermeneutický prŕstup k Blatného poezii, jak se o něj výše naznačeným způsobem pokouší Trávníček, a to především k textům pracujícím s pamětí, je marný. Tento př́stup vlastně dělá s Blatným to, co se domnívá Deleuze ${ }^{9}$, že návraty do minulosti pro spisovatele znamenají vždy — provádí tedy (řečeno deleuzovským slovníkem) Blatného reoidipalizaci. Na rozdíl od Deleuze se nedomnívám, že cesta pamětí do minulosti je nutně oidipovská: vzpomínky mě sice vracejí zpět do minulosti, ale nikoli do minulosti, která je pevná, nehybná, neměnná. Blatný se ve vzpomínkách vrací, ale neví, kde/kdy se ocitne. Kmitá z minulosti do prŕtomnosti, do budoucnosti a zpět, z porodnice na hřbitov.

Pro Blatného psaní platí to, co u poezie konstatuje Maurice Blanchot: ,jazyk opouští onen smysl, jímž chtěl výhradně být, pokouší se učinit bezesmyslným. Hlavní úlohu hraje vše, co je fyzické: rytmus, váha, masa, figura, a poté papír, na který píšeme, stopa inkoustu, kniha“10. U Ivana Blatného tento materiální, fyzický rozměr proniká do jeho poezie v podobě úvah nad papírem, na nějž píše, otázky, zda bude mít dost cigaret: „Všecky moje papíry jsou přeházené mám úzkost / mám si vzít popelníček nebo házet špačky na zem / vezmu si popelníček... [...] Nechci mít básně roztroušené po celé nemocnici“"11, konstatování, že Antonín Brousek některá slova při redakci Starých bydlišt’ deformoval nebo špatně přečetl: „Hodiny vodné hodiny piesočné / Brousek to změnil na Hodiny vodní“12 a podobně. Zároveň se jeho psaní točí kolem věcí tělesných, fyzických a konstatuje neoddělitelnost „života“ od „psaní“: „Budete mě vidět, když nebudu psát? / Řeknu vám všecko“13, „péro krásně píše ale obsah inkoustu se zmenšuje / chtěl bych dostat noční tabletky a jít do postele / nemám naději na ženu / chtít umř́t nemohu kdo by mě nahradil / Give me the rally medicine / Něco dělat, jaká námaha / nic nedělat, jaká nuda"14. Kromě toho se dá $\mathrm{z}$ těchto introspektivních promluv velmi často usuzovat na aktuální Blatného stav v době psaní, pokud jej př́mo netematizuje — at' už se jedná o sexuální frustraci nebo paranoiu spojenou se strachem z možné deportace: „home-office odmítl moji žádost o naturalisaci /

\footnotetext{
9 Viz G. Deleuze, Literature and life, „Critical Inquiry“ 1997, č. 2.

10 M. Blanchot, Literatura a právo na smrt, přel. J. Fulka, „Česká literatura“ 2004, č. 2, s. 217.

11 I. Blatný, Pomocná škola Bixley..., s. 203.

12 Ibidem, s. 195.

13 Ibidem, s. 132.

14 Ibidem, s. 133.
} 
mohu být kdykoli deportován / ačkoli jsem $\mathrm{v}$ tomhle pekle přes jednatřicet let / mám pocit nesmírné úlevy že jednou mluvím pravdu“15.

Další kategorií slov, jíž Blatný využívá téměř obsedantně, jsou vlastní jména. Derrida konstatuje v již citovaných Otobiografich nutnost ,nové analýzy vlastního jména a signatury “16. Blatný tuto analýzu ve velké míre provádí. Přestože vlastní (Blatného) jméno je tím, co nás zajímá nejvíce, zároveň je asi nemožné si nepovšimnout všeobecné př́tomnosti vlastních jmen: náměstí, nemocnice, města, státy, pamětihodnosti, politici, umělci, vojevůdci, britská královna. Přicházejí do Blatného textů z paměti, z televize, novin. Jsou tam všichni. Jmenný rejstř́k Pomocné školy Bixley vydaného nakladatelstvím Triáda roku 2011 je sám o sobě fascinujícím čtením.

Podob, které na sebe bere Blatného jméno v jeho textech, je několik, a poukáži proto jen na některé z nich. V básni „Hubené ubohé tělo Ivana Blatného / neustále zraňované těmi kteří vidí / tělo plné studu pohlaví / začíná svoje šedesáté narozeniny // Šedesát směšných let / pro smích celému světu“17 narážíme na situaci, s níž už jsme se částečně potkali, když jsem zmiňoval propojenost tělesného a psaného. Objevuje se zde častý motiv strachu z toho, že budu/nebudu viděn; oproti žánrovému očekávání tu „lyrický subjekt“ nezůstává uvnitř těla, ale vystupuje z něj, aby na ně pohlédl jako na „,někoho třetího“, kdo je trpně vystaven posměchu, jemuž se není schopen nijak bránit. Podle všeho je tento pocit ve velké míre spjat právě s možností či ochotou se pojmenovat, pojmenovat se vlastním jménem za tu cenu, že zjistím, že pod oním jménem se skrývá kdosi cizí, druhý:

Když se pojmenovávám, jako bych si zpíval vlastní pohřební pochod: odděluji se od sebe sama, nejsem již svou př́tomností ani skutečností, nýbrž prrítomností objektivní, neosobní, prítomností svého jména, které mě přesahuje a jehož zkamenělá nehybnost mi slouží právě jako náhrobní kámen, skrývající prázdnotu. Když mluvím, popírám existenci toho, co říkám, ale popírám také existenci toho, kdo to říká: pokud moje promluva odhaluje jsoucno v jeho neexistenci, tvrdí také, že toto odhalování probíhá na základě neexistence toho, kdo je uskutečňuje, na základě jeho schopnosti odstoupit od sebe sama, být jiný než svoje bytí1 ${ }^{18}$.

V jiné básni napsané u př́ležitosti šedesátých narozenin je konečně tato možnost popsána explicitně, když dále pokračuje v úvahách o těle „Ivana Blatného“: „Je v něm také strach / strach z pěstí a kopanců / těch kteří znají jen rychlou pohodlnou smrt [...]. On zná své místo on nesmí být off side / on byl ostrakizován, on byl vyhozen ze společnosti““19. Zde nás vrací Blatný na úvod mých úvah $\mathrm{k}$ onomu „básníku zasebevražděnému společností“, mohu-li si dovolit artaudovskou parafrázi.

„Novost“ Blatného analýzy vlastního jména spočívá dle mého v tom, že je schopný ve svých textech inscenovat obě navzájem se vylučující možnosti — te-

\footnotetext{
15 Ibidem, s. 257.

16 J. Derrida, The Ear of the Other..., s. 5.

17 I. Blatný, Pomocná škola Bixley..., s. 110.

18 M. Blanchot, Literatura a právo na smrt..., s. 214

19 I. Blatný, Pomocná škola Bixley..., s. 110.
} 
dy na jedné straně ono blanchotovské fatální oddělení literatury a jejího autora, poznání, že vyslovením svého jména umírám, a na druhou stranu ono stejně fatální propojení psaní a vlastního života, jak o něm hovoří Pluháček. Zároveň však pozorujeme, jak tu jedinec, reprezentovaný vlastním jménem, vystupuje coby propojení různých „systémů“: oblast fyzického, biologického života se tu protíná s oblastí kultury, systémem sociálním, systémem lékařským a psychiatrickým, politickým. Onen biologický život je pak řízen, strukturován či organizován rozměrem osobnostním, psychickým či existenciálním, přičemž je možné jej skrze psaní zkusmo promítat a napojovat na prítomnost, minulost a budoucnost.

Zdá se, že i cizí vlastní jméno si vynucuje pro své úspěšné užití absenci, či onu „smrt" o níž píše Blanchot. Jako by teprve skrz tuto nepřítomnost nositele vlastního jména a tudíž skrze nesmyslnost takové „komunikační situace“ bylo možné použít oslovení vlastním jménem téměř v magickém významu, kdy jména zhmotňují či přivolávají jejich nositele: „chodím mezi budovou nemocnice a farmou / snad budu mít nějakou návštěvu / snad mě najdou / snad se na cestě objeví Brušák / anebo Listopad / anebo Dresler / jsou tady v cizině léta a ještě jsem je neviděl / mám připraveny básně / budeme mluvit o literatuře / svět bude zase plný živo-

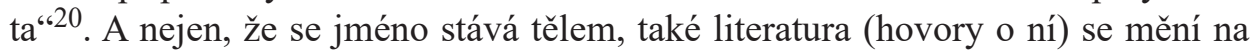
život, naplňuje svět životem.

Závažná otázka, která se zároveň s problematikou vlastního jména otevírá, je otázka po autorství či autorovi, derridovským slovníkem řečeno: otázka po signatuře či parafě. Je ji však nutno položit jinak, než ji literární věda a literární historie běžně klade. Listy papíru s básněmi, které po sobě zanechává Ivan Blatný v procesu své básnické tvorby, vykonávané převážně na psychiatrických odděleních anglických nemocnic, at' už psané rukou nebo na stroji, jsou anonymní. Na druhou stranu jou pro zrrízence příslušných institucí vybaveny přinejmenším obecnou parafou pacienta psychiatrické kliniky. Tato parafa opravňuje takového zř́zence legitimně podobné umělecké projevy vyhazovat či ničit, nebot' svůj (psychoterapeutický/arterapeutický) účel dle nich již splnily. Možná z Blatného tvorby v koši neskončilo nic, možná toho bylo až př́liš (jak naznačuje Trávníček).

Přesto se domnívám, že na Blatného psaní není nejzávažnější výsledek, konečná podoba, $v$ níž jsou jednotlivé básně a sbírky publikovány, komu projdou rukama. Vše to, čím se tak obsedantně zabývají dějiny literatury, činí samotný zpưsob Blatného psaní (at' už ve smyslu vznikání básní nebo jejich „výsledku“) vlastně irelevantním. Blatného psaní už nepatří dějinám, tedy dějinám (české) kultury nebo literatury; jeho psaní si vytváríí vlastní dějiny, vlastní panteon, vlastní kontexty, pojmenovává své vzory, fantazie, fascinace. Jeho psaní ví, kam patří a kam se chce zařadit; ví, odkud jde, s čím se potkalo, kde je nechtějí, odkud bylo vyloučeno. Psaní nezapomíná. Psaní je nezapomínání, hra na nezapomínání. Zapsaná pamět' rovná se nemožnosti zapomenout. Prostřednictvím psaní se pamět’ stává čitelnou. Jde o vzkřriššní a zároveň manifestaci paměti, jde o její (re)konstrukci. Mluvíme-li

20 I. Blatný, Stará bydliště..., s. 22. 
však o paměti, at' už o paměti osobní nebo o intervenci paměti „kulturni'“, potom je nám jisté signatury potřeba. Není jí ale „Ivan Blatný“, syn Lva Blatného, autor sbírek Melancholické procházky, atd. — tato signatura má smysl v již zmíněných dějinách literatury a kultury. Pokud už na „Ivana Blatného“ narazíme, potom vždy jen jako na „osobu třetí“, na „něho“ jak už jsem ukázal. V dějinách na sebe tento typ signatury krom jiných bere onu podobu a plní tu funkci, o níž hovoří v souvislosti s ,autorem“ Michel Foucault: referuje k ,autorovi“ v tom smyslu, jak tohoto pojmu užívá textová kritika opírající se o křest’anskou exegetickou tradici ${ }^{21}$. Opět: je to pohyb, který přisuzuje Blatnému Trávníček. Pokud nahradíme pojem „dílo“ pojmem ,psaní", potom vskutku je možné s Foucaultem říci, že tento pojem nám umožňuje zároveň uchopit jiným způsobem i pojem ,autor“, nebot' „psaní se rozvíjí jako hra, jež neměnně překračuje svá pravidla a vykračuje takto vně“, přičemž „psaní je nyní svázáno s obeetí, dokonce s obětí života: s dobrovolným ústupem do pozadí, jež ani není zastoupeno v knihách, protože je dovršeno v samotné existenci spisovatele“22.

Martin Pluháček v editorské poznámce ke Starým bydlištím konstatuje, že Blatný je autorem všech básní sbírky, ale není autorem sbírky ${ }^{23}$. Z hlediska textologického to jistě dává smysl, z hlediska mimo textologii (mimo zmíněnou exegetickou tradici) se stává věc problematičtější. A to nejen proto, že se tak znejistuje to, co vidím na přebalu: kupuji si, držím v rukou „Brouskovu“ knihu, tvořenou Blatného básněmi. Vlastní jméno, které má držet pamět' (a knihu) pohromadě (a naopak - pamět' vybavující subjekt, nositele vlastního jména minulostí či historií), jméno jakožto centrum, které má být zárukou, že je vázáno na pamět' „jednoho konkrétního člověka“, se tu problematizuje.

O jakou signaturu, podpis se tedy u Blatného jedná? Jak se podepisuje „psaní“ a nikoli „autor“? K čemu je nám vlastně signatura, podpis? Pamět’ je neviditelná, signatura ve vztahu k psaní napojenému na pamět', napájenému pamětí, (re) konstruující minulé, garantuje, že podobu, již nabyly části paměti ve slovech viditelných na papíre, jí podle „nositele“ paměti odpovídá, stvrzuje a přihlašuje se tak k práci, již podepsaný provedl. Stvrzuje se tedy akt psaní, nikoli „dílo“či ,jazykový objekt" ani jeho „výsledek“. Signatura představuje (byt' často předstíranou nebo spiše inscenovanou) záruku, že zapsané přijímá signatář za „své“ — auto-bio-grafické. A je irelevantní, zda se jedná o lež, neuvědoměný sen, pravdu, fantazma. Onu garanci nabízí signatura za všech okolností.

Nejvýmluvnější podobu této signatury, která nás přivádí $\mathrm{k}$ názvu mého příspěvku, nalezneme zde: „Mám všecko vyřešeno / jídlo mě vzpruží / it is a terrible world / terre I. Bl. / nemohu to vysvětlovat v semináři /surrealisté porozumi““24. Zde nám psaní vytyčuje konkrétní území, a to hned dvakrát (anglicky, latinsky). Území

${ }^{21}$ M. Foucault, Co je to autor?, [in:] idem, Diskurs, autor, genealogie, přel. P. Horák, Praha 1994, s. 51-52.

22 Ibidem, s. 45.

23 M. Pluháček, Ediční poznámky, [in:] I. Blatný, Stará bydliště..., s. 103.

24 I. Blatný, Pomocná škola Bixley..., s. 148. 
jazykové, dle všeho nepř́liš př́ívětivé. I. Bl. představuje zároveň souřadnice země, kam tento podpis patř́, prozrazuje způsob, jímž je tato země vytvořena a je zároveň zkratkovitým popisem, jak je v takové zemi možné se pohybovat. Bylo by chybou označit tuto zemi za pouhou zemi jazyka a paměti: jazyka paměti a paměti jazyka. Je to země-nezemě (jsme a nejsme přece v Anglii): je cizí, mluví tam jinak než doma, proto je potřeba o ní hovořit, označovat ji, odkazovat na ni cizím slovem, třeba latinou. Je cizí, ale chci aby se stala mou (připomínám již zmíněný strach Blatného z možné deportace). Chci, aby se cizí stalo mým a signatura mi nabízí to, co neudělá byrokratický britský systém: signatura mi tuto cizí zemi přivlastňuje, jako když nakreslím mapu, kterou signuji, a jaký je lepší jazyk k popisu této cizí země než cizí jazyk (angličtina), jazyk, který si jazykovou hrou přivlastňuji a činím „svým“ prací, kterou jsem na něm provedl, násilím, kterému jsem vystavil jeho slova. Aby však tato signatura fungovala, je nutné za ni ručit svým životem a svou smrtí, vepisovat jaksi na oplátku, jako daň svi̊j život do jazyka. Přesto: ta země Ivana Blatného je zároveň děsivá (terrible), traumatizující, nese v sobě pro mě zprávu, že pro mě nikdy domovem, mou, nebude. Vepisuji tedy sebe skrze cizí jazyk do cizího prostoru, vypisuji to, co je ve mně cizí, činím tak slovy, činím tak svým jménem, jsem slovo, žiji a umírám slovy, jsem v nich doma, ony mě vedou do minulosti a do budoucnosti, já si je tu ted' a tady tvořím, píšu, sepisuji, rukou nebo na stroji. A to násilí, jímž drží tento strašlivý svět pohromadě, násilí jazyka a podpisu je zároveň $\mathrm{v}$ těchto textech, v tomto psaní nezakryté, ,je vidět“. Nic není skryto. Proto tak často používá Blatný slovo „naked / nahý“. To slovo tu není k interpretaci, nemá nic společného s nějakou intimitou (v Blatného básních není žádná intimita): to slovo je tu modelem, územím i garancí zapsaného. Modelem: takto (nezakrytě) proniká před očima čtenáře psaní coby tělesný akt oblast smyslu, takto všem na očích se tu investuje tělo básníka právě do takového aktu.

$* * *$

Úloha příběhu při (re)konstrukci životního př́iběhu je nezastupitelná. S ní neodmyslitelně souvisí „práce“ (v psychoanalytickém smyslu onoho termínu), již konstrukcí prríběhu vykonáváme při budování toho, co bychom snad mohli nazvat „osobní identitou“ (kognitivní naratologie právě proto zdůrazňuje funkci př́iběhu a jeho tvorby při konstrukci vlastního já či identity — která se tak stává identitou narativní). Zároveň s sebou však zpětná (re)konstrukce toho, co se „opravdu“ událo, co subjekt ,prožil“", prostřednictvím př́běhu nese, at' už v psychiatrické, životní nebo spisovatelské praxi jisté ne zcela zjevné důsledky. Jedná se především o znejistění hranice mezi konstrukcí a rekonstrukcí - mezi popisem a fabulací. To není zjištění nijak překvapivé, nebot' toto východisko přiznávají více či méně otevřeně všechny př́iběhy tematizující pamět či minulé trauma: sepisování či sestavování př́běhů z útržků, zavádění chronologického pořadí je natolik závažným zásahem do fragmentární (pamětové) struktury minulého, že se tato činnost stává stejně podstatnou jako zpracovávaný materiál „skutečných“ událostí. V neposled- 
ní řadě je to také zcela konkrétní a „skutečná“ činnost, již píšící subjekt vykonává v době psaní. Tuto polohu v její „nenarativní“ poloze nalézáme i u Blatného.

Narážíme-li však v př́ipadě autobiografických textů na tematizaci jejich tvorby či vzniku, tematizuje-li se rekonstrukce paměti či minulosti, nelze v takovém př́padě v souvislosti s autobiografickými texty hovořit o metanarativitě či metafikcionalitě v běžném smyslu (tedy ve smyslu něčeho, co zpochybňuje referenční, iluzivní charakter narativu) — ona „sebereflexe“, k níž dochází, není trpným zrcadlením utváření prríběhu, postav, komentářem role vypravěče, není „intelektualizujícím" postupem, nýbrž zdůrazňuje nerozpojitelnost a vzájemnou podmíněnost události a jejího narativního zachycení.

Vycházím z předpokladu, že narativní zachycení minulého, vypořádání se s traumatem a podobně nutí minulosti chronologii, jíž nedisponuje nutně a přirozeně - to se týká především toho, porovnáme-li výsledný př́běh s fragmentární, neucelenou, nekoherentní topologií paměti. Tuto specifickou topologii či strukturu narativ „napravuje“, rekonstruuje předpokládaný žitý celistvý předobraz, z nějž pamět' (spolu se vzpomínkami jiných postav, dopisy, které mohu podržet v ruce, fotografiemi a podobně) zachovala právě ony zmiňované trosky či fragmenty.

Poezie Ivana Blatného z doby jeho pobytu ve Velké Británii čelí stejným problémům jako narativní zachycení minulosti a paměti. Nabízí však odlišnou možnost (psaní), strukturovanou jinak než narativní rekonstrukce paměti či minulosti. Poezie, lyrická poezie především (jakkoli jsou tyto pojmy u Blatného nutně provizorní a čistě uzuální, jak jsem poukázal), není nucena se řídit strukturou př́běhovou, a umožňuje tak zachytit pamět' minulého v její podobě nekoherentní, nesoudržné, v konkrétním smyslu nahodilé. Kontingence spočívá právě v tom, že pamět' směšuje zážitky či počitky, vjemy a vněmy skutečné, snové, estetické, tělesné bez toho, aby je zasazovala do konkrétního (jim přirozeně přináležejícího, „správného") časového ale i prostorového kontextu — chronotopem poezie je samotná neuspořádaná pamět’ a v jiné podobě popsaná stránka. Jestliže je možné souhlasit s tím, že narativní akt je aktem kognitivním, potom Blatného poezie je povýtce aktem existenciálním, tělesným.

A nejen jím. Blatného „pamět"“ má několik podob, které spolu mohou korespondovat či komunikovat, nikoli však nutně. Je pamětí kultury, místa a jazyka. Je rekonstrukcí kulturně dějinného okamžiku avantgardy, Brna meziválečného období. Je záznamem procesu — učení se cizímu jazyku, je opakováním informací z televize, novin, školních učebnic, slovníků. Zachycuje problémy s angličtinou. A slova mohou být také magická — to je ono volání těch, kdo tu nejsou ,jmény“:

Valentin Petorose, Ota Ornest, jména, jména, / jména skutečná a jména vymyšlená, / Picasso, Pignon, Lhoták, Matisse, Braque, / Vítězslav Nezval, Klement Bochořák. // V rue Jacob v Paříži je malé knihkupectví, / kde za sklem uvidíte jména mého dětství — / Salvator Dali, Dumas, Eluard, / Benjamin Péret, Tanguy, René Char. // Beer, Binder, Blatný — k tabuli jsem volán, / Adámek, Bartoš, stěhování Holan, / Dvořáček, Hora, Jahn — / a už jsem stěhován ${ }^{25}$.

25 I. Blatný, Stará bydliště..., s. 65. 
Tato osobní rekonstrukce jisté kultury, prostoupená (re)konstrukcí času dětství a sklonku evropské avantgardy a Blatného psaní vůbec se děje na pozadí jiného pohybu, jímž je pohyb, kterým nechává česká literatura, česká kultura a české literární dějiny zapomenout na Blatného, který si je tohoto snažení vědom.

Blatný zapomíná, přiznává se k nevědomosti, ke strachům, ke slabostem, začasto tělesným. Česká kultura na Blatného také zapomíná, činí tak však zpočátku naopak „hlasitě“, aby jej posléze nechala obestřít tichem, nechala na něj zapomenout. Kultura, která ve své oficiální podobě Blatného zamlčuje, vylučuje jej, $\mathrm{v}$ dějinách literatury jej obestírá tichem, se ve své polistopadové podobě snaží toto mlčení vynahradit či kompenzovat ${ }^{26}$, narativně zaplnit náhradními fantasmatickými či mytickými obsahy, nebo naopak obsahy co nejpodrobnějšími, postavenými na důkladné faktografické rešerši — to je případ románu Martina Reinera z roku 2014 Básník / román o Ivanu Blatném. Kultura vzpomíná na Blatného, ted’už samozřejmě v rámci svého diskurzu správně — tedy v podobě narativu, at' už historiografického, literárněhistorického, interpretačního, nebo románového. Otázkou je, jaké povahy tato rekonstrukce je: bud' kultura Blatného vytěsnila, a ted' se jej snaží rekonstituovat sama pro sebe (do slova a do písmene z jeho popela) - nebo se odhodlá přiznat $\mathrm{k}$ vědomému zapomnění (přičemž je otázka, jak důvěryhodně působí obrana ve smyslu: to udělali oni, to ta jejich, oficiální kultura, za vše může politická objednávka). Tímto přiznáním (k němuž však nedochází ani náznakem) by se zřejmě celá kultura traumatizovala: tím, že by se doznala k násilí, zranění, nezcelitelné jizvě, vymazání (kulturní) paměti, k rozsudku smrti.

\section{Bibliografie}

Blanchot M., Literatura a právo na smrt, přel. J. Fulka, „Česká literatura“ 2004, č. 2.

Blatný I., Pomocná škola Bixley, ed. A. Petruželka, Triáda, Praha 2011.

Blatný I., Stará bydliště, Petrov, Brno 1992.

Blatný I., Texty a dokumenty 1930-1948, ed. J. Trávníček, Atlantis, Brno 1999.

Deleuze G., Literature and Life, „Critical Inquiry“ 1997, č. 2.

Derrida J., The Ear of the Other, přel. P. Kamuf, Schocken Books, New York 1985.

Foucault M., Co je to autor?, [in:] idem, Diskurs, autor, genealogie, přel. P. Horák, Nakladatelství Svoboda, Praha 1994.

Pluháček M., Ediční poznámky; Ivan Blatný, [in:] I. Blatný, Stará bydliště, Petrov, Brno 1992.

Šmarda J., Jak se rodil básník — Vưně dětství Ivana Blatného, „Box“ 1993, č. 4.

Trávníček J., Pod sankcí paměti, [in:] idem, Poezie posledni možnosti, Torst, Praha 1996.

${ }^{26}$ Např. J. Šmarda, Jak se rodil básník - Vưně dětství Ivana Blatného, „Box“ 1993, č. 4, s. $42-51$. 


\section{Terre I. Bl.: Ivan Blatný and the (Re)Construction of His Position within Czech Culture}

\section{Summary}

The article analyzes the relationship between the official cultural discourse, "life" and "work" of Ivan Blatný in his British exile. While pointing at several forms of the said relationship the specifics of Blatný's writing in exile are being disclosed, especially concerning the role of memory, body, and autobiography. The article sees the key strategy of writing in Blatný's treatment of proper names. It especially concentrates on the signature "I. Bl.", which points at its own ambivalence, in a way questioning the institution of authorship. Through his writing, Ivan Blatný is leaving the predominantly hermeneutic sphere of meaning and sense (aesthetics and art) and in a surrealistic gesture uses poetry writing as an existential act, embodying the material, bodily, visceral aspects of "life". The analysis is grounded in a brief outline of the differences between poetry and prose "memory" witing.

Keywords: autobiography, Ivan Blatný, cultural memory, memory, signature

\section{Terre I. Bl.: Ivan Blatný i (re)konstrukcja jego pozycji w kulturze czeskiej}

\section{Streszczenie}

Artykuł opisuje związek między oficjalnym dyskursem kulturowym, ,życiem” i „dziełem” Ivana Blatnego w trakcie jego brytyjskiej emigracji. Kilka form, które ten związek przyjmuje w przypadku Ivana Blatnego, pozwala skutecznie przeanalizować rolę pamięci, ciała i autobiografii w jego twórczości. Artykuł zwraca szczególną uwagę na sposób, w jaki Blatný traktuje własne nazwiska, w czym upatruje jeden z głównych kluczy specyfiki tej poezji. Autor koncentruje się na podpisie „I. BI.”, który jest skonstruowany jako dwuznaczny, kwestionujący na swój sposób instytucję autorstwa. Swoim pisaniem Blatný opuszcza hermeneutyczną sferę znaczenia i celu (estetyki i sztuki), gdy w swego rodzaju surrealistycznym geście angażuje się w sferę egzystencjalną, podczas gdy pismo reprezentuje materialny, fizyczny, wewnętrzny aspekt „życia”. Analiza oparta jest na krótkiej charakterystyce różnic między poezją a prozą zajmującą się pamięcią.

Słowa kluczowe: autobiografia, Ivan Blatný, pamięć kulturowa, pamięć, podpis 